\title{
Suhu Air Laut Tahunan di Perairan Pulau Genting, Kepulauan Karimunjawa
}

\author{
Arfiyan $^{1)}$ dan Munasik ${ }^{2)}$ \\ ${ }^{1)}$ PT Pura Baruna Lestari, Pulau Sambangan Kepulauan Karimunjawa, Kabupaten Jepara - Jawa Tengah \\ ${ }^{2)}$ Jurusan ilmu Kelautan, Fakultas Perikanan dan Ilmu Kelautan - Universitas Diponegoro \\ Email : munasik@undip.ac.id
}

\begin{abstract}
Abstrak
Kombinasi data suhu air laut dari pengukuran lapangan secara tahunan dan data meteorologi Near Real Time dari satelit bisa digunakan sebagai acuan untuk mengaitkan kondisi musim suatu perairan. Kondisi Perairan Pulau Genting mempunyai dua pola suhu rendah yaitu pada musim monsoon barat laut JFM (Januari, Februari, Maret) dan musim monsoon tenggara JAS (Juli, Agustus, September). Sedangkan pola suhu tinggi terjadi pada musim transisi AMJ (April, Mei, Juni) dan musim transisi OND (Oktober, November, Desember). Pola suhu air laut tahunan menunjukan bahwa suhu tahunan di Pulau Genting sangat dipengaruhi oleh kecepatan angin dibandingkan Insolation Clearness Index dan Curah Hujan pada semua musim.
\end{abstract}

Kata kunci: Suhu Air Laut Tahunan, Musim, Kecepatan Angin

\begin{abstract}
In situ annual seawater temperature record combine with Near Real Time satellite meteorology can use to correlation season in ocean. Genting Island waters have two pattern lower temperature there are Northwest Monsoon Season JFM (January, February, March) and Southeast Monsoon Season JAS (July, August, September). In other side higher in transition period AMJ (April, May, June) dan transition period OND (October, November, December). Annual seawater temperature pattern in Genting island Waters very influence by wind speed other than Insolation Clearness index and Rainfall in all Season.
\end{abstract}

Key words: Annual Seawater Temperature, Seasoon, Wind Speed

\section{PENDAHULUAN}

Kepulauan Indonesia merupakan Negara kepulauan yang berada di equator yang perubahan massa airnya dipengaruhi oleh Samudra Pasifik dan Samudra Hindia. Karena terletak diantara dua Samudra yang luas maka, terjadi pepindahan massa air yang disebut dengan Arus Lintas Indonesia. Kepulauan Indonesia juga dipengaruhi oleh adanya angin Monsoon Tenggara dan Monsoon Barat Laut yang sangat mempengaruhi kondisi perairan dan musin di Indonesia. Suhu permukaan air laut di perairan Indonesia sangat penting dan berhubungan dengan distribusi curah hujan di Indonesia. Distribusi suhu permukaan laut di Indonesia sangat komplek bervariasi waktu dan tempat. Perbedaan proses penyebab dan perbedaan waktu juga berbeda kondisi suhu permukaan laut di setiap wilayah $(\mathrm{Qu}$ et al, 2005).

Variasi musiman perubahan suhu permukaan laut di Laut jawa termasuk dalam Semi Annual dimana suhu permukaan laut sedikit berubah setiap tahunnya dan tertinggi pada musim transisi yaitu bulan April dan November (Sachoemar, S.I and Yanagi T., 2000). Perubahan suhu permukaan Laut Jawa sangat dipengaruhi oleh transfer panas (Heat Flux). Analisa suhu air laut Perairan Indonesia banyak digunakan untuk memprediksi upwelling (Susanto et al., 2001; Kunarso et al., 2005; Habibi et al., 2010), interaksi angin dan pendinginan air laut (Setiawan, R.Y dan A. Habibi, 2010) dan

\footnotetext{
*) Corresponding author

buloma.undip@gmail.com

http://ejournal.undip.ac.id/index.php/buloma

Diterima/Received : 12-02-2016

Disetujui/Accepted : 20-03-2016
} 
mengkaji fenomena El-Nino Southern Oscilation (Nichols N, 1984; Susanto et al., 2001).

Kepulauan Karimunjawa merupakan salah satu lokasi fishing ground yang terletak di Laut Jawa dengan kondisi eksploitasi ikan pelagis dan ikan karang yang sangat besar (Edinger et al, 2000). Laut Jawa merupakan dominan tangkapan ikan pelagis yang dipengaruhi oleh perubahan musim Monsoon yang berhubungan dengan suhu air laut (Hendiarti et al., 2005). Dalam penelitian ini bertujuan untuk menganalisa perubahan suhu air laut tahunan di Pulau Genting Kepulauan Karimunjawa.

\section{METODE}

Penelitian ini dilakukan dengan metode pengambilan data lapangan dengan $H O B O$ Pendant Underwater Temperature /Light Data Logger 64K pada kedalaman 3,5 meter di sekitar Perairan Pulau Genting Kepulauan Karimunjawa. Alat ini akan mengukur dan merekam secara otomatis temperetur air laut $\left({ }^{\circ} \mathrm{C}\right)$ dan intersitas cahaya (Lux) dengan interval satu jam mulai tanggal 24 April 2012 sampai dengan 29 Maret 2014. Sehingga tercatat kondisi suhu air laut pada saat semua musim setiap tahunnya.

Data series diambil dari NASA Climatology Resource Near Real-time Global Radiation and Meteorology untuk studi proses klimatologi meliputi data meteorologi jangka panjang dan solar energy flux dengan perkiraan resolusi grid $1^{\circ} \times 1^{\circ}$ (http://power.larc.nasa.gov/). Data yang diambil kecepatan angin, curah hujan dan Insolation Clearness Index dengan koordinat Latitude $-5,8$ Longitude 110,5 dari tanggal 24 April 2012 sampai dengan 29 Maret 2014. Pada koordinat tersebut wilayah penelitian masuk pada cell data series.

\section{HASIL DAN PEMBAHASAN}

Variasi suhu tahunan menunjukkan pola yang tetap dimana setiap tahun terdapat dua kali periode suhu (Gambar 1.d). Suhu cenderung rendah pada bulan JFM (Januari, Februari, Maret) dan pada bulan JAS (Juli, Agustus, September). Periode suhu rendah bulan JAS berkisar $28^{\circ} \mathrm{C}-29^{\circ} \mathrm{C}$. Sedangkan periode suhu dingin bulan JFM berkisar $27,5^{\circ} \mathrm{C}-$ $30,5^{\circ} \mathrm{C}$. Periode suhu dingin JFM sangat dipengaruhi oleh kecepatan angin monsoon yang tinggi mulai akhir Desember. Angin Monsoon pada bulan ini dominan dari arah Barat Laut yang membawa massa air yang dingin dari Laut China Selatan (Qu et al, 2005). Massa air dingin tersebut yang melalui Selat Karimata yang berkontribusi positif hanya pada musim barat (Boreal Winter) terhadap Arus Lintas Indonesia yang akan bertemu dengan arus dari Selat makassar yang melalui Laut Jawa (Fang et al, 2010). Namun pada bulan Februari 2013 terdapat anomali kenaikan suhu dibandingkan pada bulan Februari 2014. Hal ini terjadi karena pada musim tersebut terjadi kecepatan angin yang rendah disertai curah hujan yang rendah selama beberapa hari, sehingga sinar matahari tidak terhalang oleh awan. Dapat dilihat dari nilai Insolation Clearness Index (Gambar 1.a) yang lebih tinggi dibandingkan ketika waktu curah hujan yang tinggi (Gambar 1.b). Hal ini menunjukan bahwa pemanasan sinar matahari langsung mempengaruhi kenaikan suhu pada musim hujan jika kondisi cerah dan kecepatan angin yang rendah selama beberapa hari. Kawai dan Wada (2007) juga menyatakan bahwa pemanasan suhu permukaan laut sangat jelas dipengaruhi ketika kecepatan angin lemah dan Solar Insolation yang kuat. Sedangkan penurunan suhu pada periode JFM di Pulau Genting sangat dipengaruhi transport Arus Lintas Indonesia dari Laut China Selatan yang melalui Selat Karimata.

Periode suhu dingin JAS (Juli, Agustus, September) terjadi pada musim angin monsoon tenggara yang berhembus dari benua Australia membawa uap air yang kering. Walaupun membawa uap air yang kering, namun suhu air laut cenderung dingin. Hal ini karena angin tersebut bertiup dari tenggara yang membawa air dingin Upwelling dari Laut Banda. Pada Bulan Agustus merupakan puncak dari suhu air laut dingin (Setiawan, R.Y dan A. Habibi, 2010). Pada Bulan Agustus 2012 suhu rata-rata $29,5^{\circ} \mathrm{C}$ dan pada Bulan Agustus 2013 suhu rata-rata $29{ }^{\circ} \mathrm{C}$ (Gambar 1.d). Meskipun kecepatan angin pada Bulan Agustus 2012 lebih rendah dibandingkan pada Bulan Agustus 2013 namun suhu air laut rata-rata lebih rendah. Meskipun kecepatan angin yang berbeda pada periode suhu dingin JAS namun suhu tahunan mempunyai pola yang sama setiap tahunnya. Sedangkan pola suhu yang cenderung tinggi juga terjadi dua kali setiap tahunnya yaitu pada bulan AMJ (April, Mei, Juni) dan bulan OND (Oktober, November, Desember) dimana pada periode tersebut wilayah Indonesia mengalami musim 
Transisi. Pada kedua periode ini mempunyai pola yang sama dimana suhu air laut antara $29^{\circ} \mathrm{C}-31^{\circ} \mathrm{C}$. Pada periode AMJ maupun OND kecepatan angin lebih rendah dibandingkan saat periode JFM dan JAS (Gambar 1.c). Jelas terlihat pengaruh kecepatan angin sangat mempengaruhi kenaikan suhu air laut pada musim transisi di Pulau Genting. Pola tahunan menunjukan bahwa suhu tahunan di Pulau Genting sangat dipengaruhi oleh kecepatan angin dibandingkan Insolation Clearness Index dan Curah Hujan pada semua musim. Walaupun Kawai dan Wada (2007) menyatakan pemanasan suhu permukaan laut sangat jelas dipengaruhi ketika kecepatan angin lemah dan Solar Insolation yang kuat namun pola suhu tahunan di Pulau Genting jelas dipengaruhi oleh kecepatan angin. Disisi lain kondisi bathimetri laut jawa yang berupa paparan continental menjadikan variasi tahunan suhu air laut yang secara langsung dipengaruhi transport massa air dari Selat Karimata dan Laut Banda.

\section{SIMPULAN}

Pola suhu air laut tahunan menunjukan bahwa suhu tahunan di Pulau Genting sangat dipengaruhi oleh kecepatan angin dibandingkan Insolation Clearness Index dan Curah Hujan pada semua musim.

\section{DAFTAR PUSTAKA}

Yoshimi Kawai and Akioshi Wada. 2007. Diurnal sea surface temperature variation and its impact on the atmosphere and ocean: A review, Journal of Oceanography 63:5, 721744

Fang, G., R. D. Susanto, S. Wirasantosa, F. Qiao, A. Supangat, B. Fan, Z. Wei, B. Sulistiyo, and S. Li. 2010. Volume, heat, and freshwater transports from the South China Sea to Indonesian seas in the boreal winter of 20072008, J. Geophys. Res., 115, 12020,

Sachoemar, S.I and Yanagi T. 2000. Seasonal Variation in Sea Surface Temperature around Java derived from NOAA AVHRR. La Mer
Societe franco-japonaise d'oceanographie, 38: $65-75$

Edinger, E. N., Kolasa, J. and Risk, M. J. 2000. Biogeographic variation in coral species diversity on coral reefs in three regions of Indonesia. Diversity and Distributions, 6: 113-127

Nicholls N. 1984. The southern oscillation and Indonesia sea surface temperature. Monthly. Weather Review 112: 424-432.

Susanto, R. D., Gordon, A. L. \& Zheng, Q. N. 2001. Upwelling along the coasts of Java and Sumatra and its relation to ENSO. Geophys. Res. Lett. 28, 1599-1602

Habibi, A., R.Y. Setiawan and A.K Zuhdy. 2010. Wind-driven Coastal Upwelling Along South of Sulawesi Island. Majalah Ilmu Kelautan, 15 (2) $113-118$

Setiawan, R. Y. \& A. Habibi. 2010. SST Cooling in Indonesian Seas. Majalah Ilmu Kelautan, 15 (1) 42 - 46

Kunarso, N. S. Nining dan A. Supangat. 2005. Karakteristik Upwelling di Sepanjang Perairan Selatan NTT Hingga Barat Sumatera. Majalah Ilmu Kelautan, 10 (1) : 17 $-23$

Hendiarti, N., Suwarso, E. Aldrian, K. Amri, R. Andiastuti, S.I. Sachoeman, and I.B. Wahyono. 2005. Seasonal Variation of Pelagic Fish Catch Around Java. Oceanography Magazine, 18 (4): 112-123.

Qu, T., Y. Du, J. Strachan, G. Meyers, \& J. Slingo. 2005.Sea surface temperature and its variability in the Indonesian region. Oceanography Magazine, 18 (4): 50-61. 

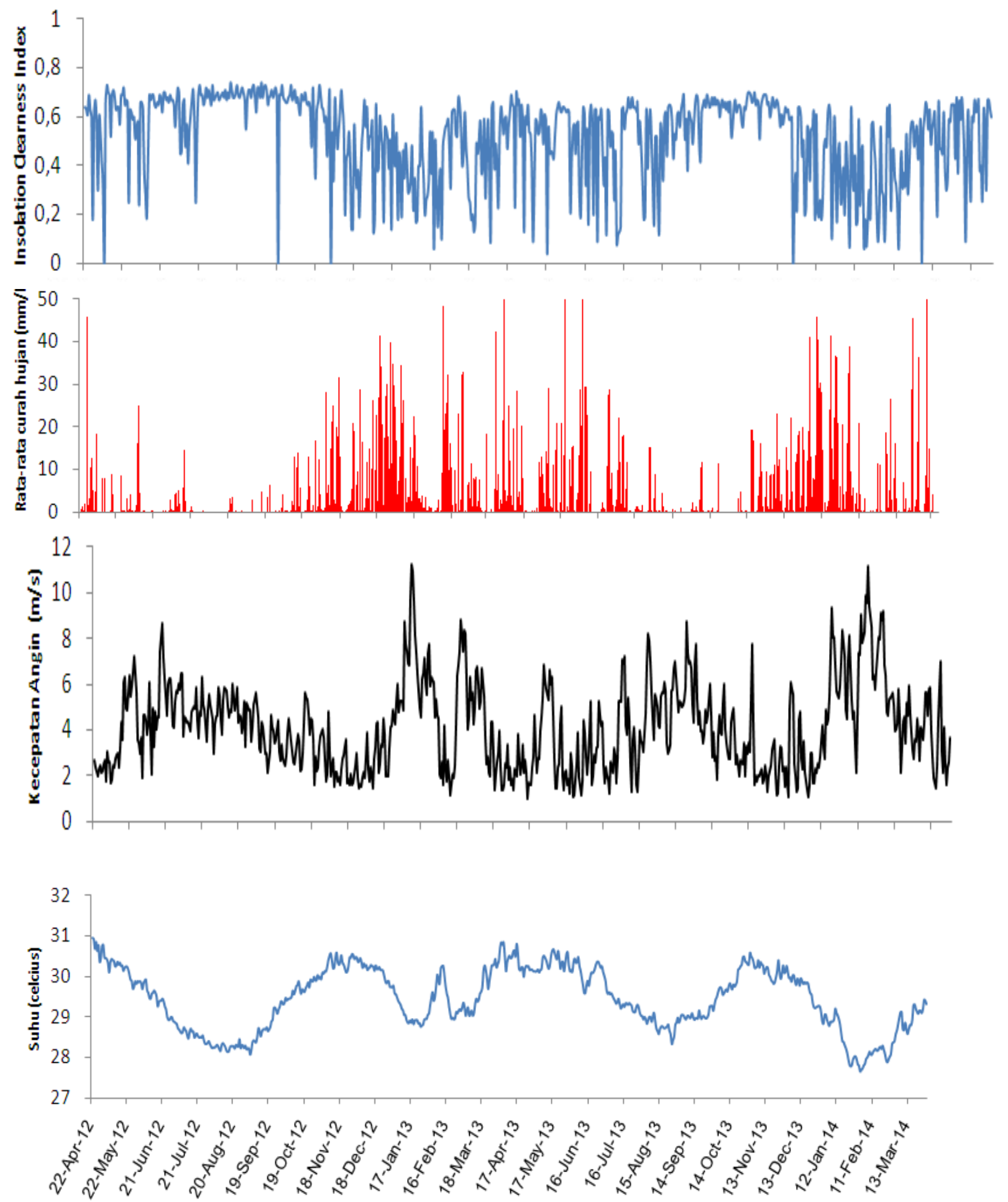

Gambar 1. Grafik dari NASA Climatology Resource Near Real-time Global Radiation and Meteorology untuk Insolation Crearness index (a), Rata-rata curah hujan (mm/day) (b), Kecepatan Angin (m/s) (c) dan data lapangan suhu air laut (d) 